\title{
Integritas, Objektivitas, Profesionalime Auditor dan Kualitas Audit di Kantor Akuntan Publik Jakarta Selatan
}

\author{
Pria Andono Susilo ${ }^{1}$ Tri Widyastuti ${ }^{2}$ \\ ${ }^{1,2}$ Universitas Pancasila, Jl. Srengseng Sawah, Jagakarsa, Jakarta Selatan 12640
}

\author{
I N F O A R T I K E L \\ JEL Classification: \\ M42 \\ H83
}

Keywords:

integrity,

objectivity,

professionalism

and quality audits

\section{A $B$ B S T $R$ R A $A$ T}

Audit quality is the possibility of finding and reported a violation of the client's accounting system. This study aims to examine the influence influence the integrity, objectivity and professionalism of auditors on audit quality. The study used survey method in January to March 2014. Research sampling method based on convenience in the election samplel by destination. Respondents many as 82 people. The data analyzed using regression methods. The results indicate variable integrity, objectivity and professionalism of auditors affect simultaneously and can be used to predict the quality of audit results. From the research hypothesis can result in that variable integrity of auditors have a significant positive effect on audit quality. Professionalism variable also has a significant positive effect on audit quality but objectivity variable has no significant effect on audit quality .

\section{A B S T R A K}

Kualitas audit adalah kemungkinan menemukan dan melaporkan pelanggaran sistem akuntansi klien. Penelitian ini bertujuan untuk menguji pengaruh mempengaruhi integritas, objektivitas dan profesionalisme auditor terhadap kualitas audit. Penelitian ini menggunakan metode survei di Januari - Maret 2014. Metode penelitian sampling berdasarkan kenyamanan dalam pemilihan samplel oleh tujuan. Responden sebanyak 82 orang. Data dianalisis dengan menggunakan metode regresi. Hasil penelitian menunjukkan integritas variabel, objektivitas dan profesionalisme auditor berpengaruh secara simultan dan dapat digunakan untuk memprediksi kualitas hasil audit. Dari hipotesis penelitian dapat menghasilkan bahwa integritas variabel auditor memiliki efek positif yang signifikan terhadap kualitas audit. Variabel Profesionalisme juga memiliki efek positif yang signifikan terhadap kualitas audit, tetapi variabel objektivitas tidak berpengaruh signifikan terhadap kualitas audit.

\section{Pendahuluan}

Profesi sebagaiakuntan publikmemainkan peranan sosial yang sangat penting berhubungan dengan tugas dan tanggung jawab yang diemban oleh auditor. Akuntan publik dalam menjaga mutu pekerjaan profesionalnya yang harus berpedoman pada Kode Etik Akuntan Publik maupun Standar Profesional Akuntan Pubik
(SPAP). Seorang akuntan publik yang profesional merancang audit untuk memberikan keyakinan bahwa laporan keuangan tidak dipengaruhi oleh salah saji (mistatement) yaitu kekeliruan (error) dan kecurangan (fraud). Jika para pengguna jasa tersebut sudah tidak memiliki keyakinan pada para auditor maka kemampuan mereka untuk melayani klien serta masyarakat secara efektif akan

*Email Korespondensi: 'priaandono@yahoo.com, triewidhiastuti@yahoo.com 
terhapuskan (Arens,Elder,dan Beasley,2011:105). Tetapi masih banyak kasus yang bisa kita lihat dimana peranan auditor belum sebagai profesi profesional yang harusnya memberikan efek jera pada pelaku bisnis yang curang dan tak bermoral, yang berakibat para pengguna laporan keuangan mulai mempertanyakan eksistensi auditor sebagai pihak independen dalam menilai kewajaran suatu laporan keuangan. Hal ini tergambar dalam kasus skandal besar dunia dan di indonesia.

Di dalam UU No.5 Tahun 2011 Pasal 30 Tentang Akuntan Publik sudah jelas di tegaskan bahwa akuntan pulik dalam hal ini Kantor Akuntan Publik (KAP) di larang melakukan manipulasi, membantu melakukan manipulasi, dan/atau memalsukan data yang berkaitan dengan jasa yang diberikan. Padahal profesi akuntan mempunyai peranan penting dalam penyediaan informasi keuangan handal bagi pemerintah, investor, kreditor, pemegang saham, karyawan, debitur juga mayarakat dan pihakpihak lain yang berkepentingan. Terungkapnya skandal besar dalam dunia bisnis belakangan ini yang mempengaruhi industri keuangan, pasar modal, investor, profesi dan karyawan menurut Harahap (2008) tidak lepas dari tindakan korupsi dan kriminalitas seorang auditor. Merekalah orang-orang yang tidak memiliki etika mencoba melakukan pemalsuan angka dan penyelewengan untuk kepentingan pribadi ataupun kliennya. Kerakusan akan keuntungan material membuat ia lupa akan etika yang pada akhirnya merugikan dirinya sendiri.

Berdasarkan Standar Profesional Akuntan Publik(IAPI,2011), pelaksanaanauditolehauditor dapat dikatakan berkualitas apabila memenuhi standar pengauditan. Standar pengauditan tersebut mencakup mutu profesional auditor, independensi, pertimbangan yang digunakan dalam pelaksanaan audit,dan penyusunan laporan audit. Dengan demikian,seorang auditor dapat menghasilkan jasa ataupun laporan yang berkualitas jika auditor tersebut melaksanakan pekerjaannya secara profesional sesuai dengan ketentuan standar pengauditan yang berlaku.

Tidak mudah menjaga integritas, objektifitas dan profesionalisme dalam diri auditor agar tetap sesuai dengan jalur yang seharusnya. Hubungan kerjasama dengan klien yang terlalu dekat ataupun terlalu lama bisa menimbulkan kerawanan atas integritas, objektifitas dan profesionalisme yang dimiliki. Belum lagi fasilitas-fasilitas yang diberikan klien selama proses audit. Bukanlah hal yang tidak mungkin auditor menjadi "gampang dikendalikan" oleh klien karena auditor berada dalam posisi yang dilematis. Disatu sisi auditor harus menjaga etika profesi, namun disisi lain terkadang harus menghadapi tekanan klien dalam berbagai pengambilan keputusan. Berdasarkan hal tersebut maka penelitian yang dilakukan saat ini adalah menganalisis pengaruh integritas, objektivitas dan profesionalisme auditor terhadap kualitas audit. Hasil dari penelitian ini nantinya diharapkan sangat penting untuk tidak adanya lagi akuntan publik dan kantor akuntan publik yang akan dicabut izinnya oleh menteri keuangan. Untuk itu peneliti membuat sebuah penelitian yang berjudul "Pengaruh Integritas, Objektivitas dan Profesionalisme Auditor terhadap Kualitas Audit".

\section{Kajian Teori dan Pengembangan Hipotesis}

\section{Grand Theory}

Sebagian besar konsep (dalam beberapa hal teori) dalam study of accountant berasal dari disiplin lain terutama ilmu keperilakuan (behavioral), ilmu keprilakuan itu sendiri sebagian besar mengacu pada konsep-konsep psikologi, psikologi sosial, dan sosiologi. Stephan dalam Ghozali (2006:9-10) menyatakan bahwa terdapat dua klasifikasi tentang sikap dari para ahli psikologi modern. Pendekatan yang pertama, yang dikenal dengan pendekatan tricomponent memandang bahwa sikap merupakan interaksi antara komponen-komponen pembentuknya antara lain:

1. Kognitif meliputi kepercayaan (beliefs), ide dan konsep;

2. Afektif meliputi perasaan dan emosi, komponen ini berisi arah dan intensitas penilaian seseorang atau perasaan yang di ekspresikan terhadap objek sikap serta; 
3. Konatif atau psikomotorik yang merpakan kecenderungan untuk bertingkahlaku terhadap objek atau orang.

Pendekatan kedua timbul karena ketidakpuasan atas penjelasan mengenai inkonsistensi antar tiga komponen sikap. Pendekatan ini memandang perlunya membatasi sikap hanya pada aspek afektif dan menyatakan bahwa sikap tidak lain merupakan efek atas penilaian (positif atau negatif) terhadap suatu objek. Sikap selalu dikaitkan dengan perilaku yang berada dalam batas kewajaran dan kenormalan yang merupakan respon atau stimulus lingkungan sosial. Teori-teori yang digunakan dalam penelitian ini lebih memfokuskan kepada akuntansi keprilakuan (behavioural accounting) yang menitik beratkan prilaku seorang auditor dalam melaksanakan tugas pemeriksa laporan keuangan kliennya.

\section{Agency Theory}

Jensen dan Meckling (1976) memandang hubungan manajemen dan pemilik dalam kerangka hubungan keagenan. Dalam hubungan keagenan, terjadi kontrak antara satu pihak, yaitu pemilik, dengan pihak lain, yaitu agen. Dalam kontrak, agen terikat unt uk melakukan beberapa jasa bagi pemilik berdasarkan pendelegasian wewenang dari pemilik kepada agen untuk mengambil keputusan bisnis bagi kepentingan pemilik. Karena kepentingan kedua pihak tersebut tidak selalu sejalan, maka sering terjadi benturan kepentingan antara pemilik (prinsipal) dengan pihak yang diserahi untuk mengelola perusahaan (agen).

Dalam konteks keagenan tersebut, dibutuhkan pihak ketiga yang independen sebagai mediator antara prinsipal dan agen. Pihak ketiga ini berfungsi memonitor perilaku manajer sebagai agen dan memastikan bahwa agen bertindak sesuai dengan kepentingan prinsipal. Auditor adalah pihak yang dianggap mampu menjembatani kepentingan pihak prinsipal (shareholders) dengan pihak manajer dalam mengelola keuangan perusahaan. Auditor melakukan fungsi monitoring untuk mengawasi pekerjaan manajer melalui laporan keuangan yang dibuat oleh manajer sebagai bentuk pertanggungjawabannya pada pemegang saham.

\section{Kualitas Audit}

Kualitas kerja auditor dapat dikelompokan menjadi dua yaitu: berkualitas (dapat dipertanggungjawabkan) dan tidak berkualitas (tidak dapat dipertanggungjawabkan). Dua pendekatan yang digunakan untuk mengevaluasi sebuah keputusan yaitu outcome oriented dan process oriented. Kualitas hasil kerja berhubungan dengan seberapa baik suatu pekerjaan diselesaikan dibandingkan dengan kriteria yang telah ditetapkan. Bagi auditor, kualitas kerja dilihat dari kualitas audit yang dihasilkan yang dinilai dari seberapa banyak auditor memberikan respon yang benar dari setiap pekerjaan audit yang dapat diselesaikan (Mardisar dan Sari (2007:5). Pengukuran kualitas audit membutuhkan kombinasi antara ukuran proses dan hasil. Pengukuran hasil (outcome oriented) lebih banyak digunakan dibandingkan pengukuran proses (process oriented) karena pengukuran proses tidak dapat diobservasi secara langsung sedangkan pengukuran hasil biasanya menggunakan ukuran besarnya audit. Hal tersebut senada dengan yang ditetapkan IAPI, audit dikatakan berkualitas jika memenuhi standar auditing yang sudah ditetapkan.

\section{Integritas dan Objektivitas}

Berdasarkan Pernyataan Etika Profesi tentang integritas, objektivitas, dan independensi (Agoes, 2004:265), integritas adalah unsur karakter yang mendasar bagi pengakuan profesional yang merupakan kualitas yang menjadikan timbulnya kepercayaan masyarakat sehingga mengharuskan auditor untuk bersikap jujur dan berterus terang dalam batasan kerahasiaan. Tetapi menurut Biana,dkk (2009) untuk independensi dan integritas tidak berpengaruh signifikan terhadap kualitas hasil pemeriksaan. Objektivitas menetapkan suatu kewajiban bagi auditor untuk tidak memihak, jujur secara intelektual, tidak berprasangka atau bisa serta bebas dari konflik kepentingan atau 
berada di bawah pengaruh pihak lain.

\section{Profesionalisme Akuntan Publik}

MenurutArens (2010:87) profesionalisme adalah suatu tanggung jawab yang dibebankan kepadanya dan lebih dari sekedar dari memenuhi tanggung jawab yang dibebankan kepadanya dan lebih dari sekedar dari memenuhi Undang-Undang dan peraturan masyarakat. Profesionalisme menurut (Irwansyah, 2010:33) dapat dicerminkan kedalam lima hal, yaitu:

1) Pengabdian pada profesi, 2) Pemenuhan kewajiban sosialnya, 3) Sikap kemandiriannya, 4) Keyakinan terhadap peraturan profesi, dan 5) Kualitas hubungannya dengan sesama profesi. Objektivitas, independensi, dan standar teknis merupakan nilai-nilai intelektual yang terdapat dalam profesi auditor. Sedangkan kejujuran, integritas, kepercayaan, dan perilaku etika merupakan nilai-nilai moral yang dianggap sama pentingnya dengan nilai-nilai intelektual.

Mereka mempertegas pernyataan tersebut melalui dua kalimat berikut, "Virtue ethics emphasizes what makes up a morally good person." Dan "Competance in ethics is an important requirement of a good auditor". Beberapa penelitian tentang kualitas audit yang pernah dilakukan menyimpulkan temuan yang berbeda mengenai faktor yang mempengaruhi kualitas audit. Hasil penelitian Biana,dkk (2009) menyimpulkanbahwaintegritastidakberpengaruh terhadap kualitas audit, sementara itu dalam penelitian Mabruri dan Jaka (2010), diperoleh kesimpulan bahwa integritas auditor berpengaruh positif terhadap kualitas audit. Sedangkan untuk objektivitas dan profesionalisme hampir para peneliti terdahulu memiliki hasil yang sama yaitu berpengaruh signifikan terhadap kualitas audit.

\section{Pengembangan Hipotesis}

Berdasarkan kerangka pemikiran pada gambar 1, maka hipotesis dalam penelitian ini dapat dirumuskan sebagai berikut:

$\mathrm{H}_{1}$ : Integritas, Objektivitas dan Profesionalisme berpengaruh secara simultan terhadap Kualitas Audit

$\mathrm{H}_{2}$ : Integritas berpengaruh secara parsial terhadap kualitas audit

$\mathrm{H}_{3}$ : Objektivitas berpengaruh secara parsial terhadap kualitas audit

$\mathrm{H}_{4}$ : Profesionalisme berpengaruh secara parsial terhadap Kualitas Audit

\section{Metode}

Penelitian inibertujuan untukmenganalisa hubungan kausalitas yang digunakan untuk menjelaskan pengaruh variabel independen, yaitu integritas, objektivitas dan profesionalisme terhadap variabel dependen, yaitu kualitas audit. Populasi penelitian ini adalah akuntan yang bek-

\section{Gambar I}

Kerangka Pikir

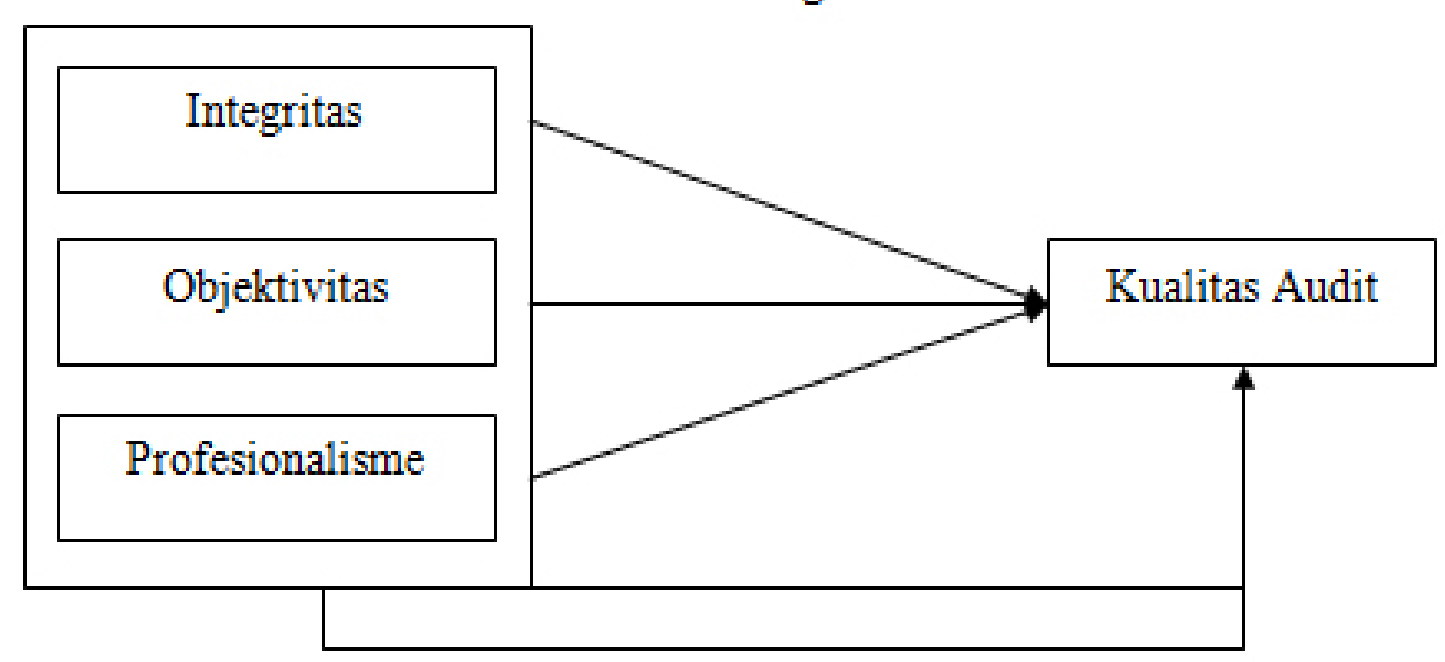


erja pada kantor akuntan publik yang berada di wilayah Jakarta Selatan yang terdaftar pada directory Ikatan Akuntan Publik Indonesia (IAPI) dimana jumlah kantor akuntan publik di wilayah jakarta selatan ada sebanyak 74 kantor.

Sampel pada penelitian ini adalah seorang auditor yang bekerja pada kantor akuntan publik wilayah jakarta selatan. Metode yang digunakan dalam pemilihan sampel penelitian adalah pemilihan sampel berdasarkan kemudahan (couvenience sampling) dalam pemilihan sempel berdasarkan tujuan (purposive sampling), dengan teknik berdasarkan pertimbangan (judgement sampling) yang merupakan tipe pemilihan sampel secara tidak acak yang informasinya diperoleh dengan menggunakan pertimbangan tertentu (umumnya disesuaikan dengan tujuan atau masalah penelitian). Kriteria yang digunakan sebagai berikut:

a. Sampel merupakan auditor yang bekerja pada Kantor Akuntan Publik yang ada di Jakarta Selatan sesuai dengan Directory Kantor Akuntan Publik 2012 yang diterbitkan oleh Institut Akuntan Publik Indonesia (IAPI). Pemilihan sempel ini dengan pertimbangan bahwa agar mudah di peroleh, dari 74 kantor akuntan publik yang ada di jakarta selatan dipilihlah sampel yang menjadi sasaran sebanyak 15 kantor dapat di lihat pada tabel dibawah ini:

b. Auditor yang bekerja di KAP yang telah dipilih oleh peneliti pada tabel 3-2, yang mempunyai Nomor Register Ak maupun tidak, dan pihak manajemen yang pernah terlibat dalam pekerjaan di bidang auditing.

c. Auditor yang mempunyai pengalaman kerja minimal satu tahun. Pengalaman kerja satu tahun dianggap telah memiliki waktu dan pengalaman untuk beradaptasi serta menilai kinerja dan kondisi lingkungan kerjanya.

Penelitian ini akan dilakukan pada kantor akuntan publik yang masih memiliki perijinan dalam melakukan jasa Assurance, Atestasi dan Jasa Non assurance yang ada di jakarta selama 3 bulan yaitu Januari s.d Maret 2014. Untuk pemilihan tempat dan waktu untuk kemudahan pengumpulan data penelitian peneliti membatasi hanya untuk 15 kantor akuntan publik yang ada di wilayah jakarta selatan saja.

Sumber data yang digunakan dalam penelitian ini dapat digolongkan sebagai data primer, yaitu data quesioner atas integritas, objektivitas, profesionalisme dan kualitas audit. Quesioner ini akan di isi oleh tiap-tiap auditor yang berada pada kantor akuntan publik yang menjadi sasaran penyebaran quesioner. Dalam memperoleh data-data pada penelitian ini, peneliti menggunakan dua cara yaitu penelitian pustaka dan penelitian lapangan. Penelitian Pustaka (Library Research), peneliti memperoleh data yang berkaitan dengan masalah yang sedang diteliti melalui buku, jurnal, penelitian terdahulu (tesis), directory kantor akuntan publik 2013, internet, dan perangkat lain yang berkaitan dengan judul penelitian. Sedangkan Penelitian Lapangan (Field Research), peneliti memperoleh data langsung dari pihak pertama (data primer). Pada penelitian ini, yang menjadi subyek penelitian adalah auditor eksternal yang bekerja pada kantor akuntan publik. Peneliti memperoleh data dengan mengirimkan kuesioner kepada kantor akuntan publik secara langsung ataupun melalui perantara. Data primer diperoleh dengan menggunakan daftar pertanyaan yang telah terstruktur dengan tujuan untuk mengumpulkan informasi dari auditor yang berkerja pada KAP sebagai responden dalam penelitian.

Variabel-variabel yang akan di operasionalkan adalah semua variabel berdasarkan hipotesis yang telah dijelaskan pada bagian sebelumnya:

1. Kualitas Audit (dependent variabel), Sebagai variabel terikat (dependent variabel) pada penelitian ini adalah Kualitas Audit (Y). Kualitas audit adalah segala kemungkinan auditor dapat menemukan kesalahan dalam laporan keuangan klien serta kekeliruan baik yang disengaja ataupun tidak disengaja yang terjadi dalam system akuntansi klien, dimana dalam pelaksanaan proses auditing seorang auditor berpedoman pada standar auditing. Untuk mengukur variable kualitas audit mengadopsi instrumen yang digunakan oleh Ika Sukriah, Akram, Biana Adha Inapty 
(2009) kuesioner yang di susun dari acuan BPKP, yaitu Kesesuaian Pemeriksaan dengan Standar Audit dan Kualitas laporan hasil pemeriksaan. Variabel ini diukur dengan menggunakan skala interval (likert) 5 poin, dari sangat tidak setuju (1), tidak setuju (2), netral (3), setuju (4), dan sangat setuju (5).

2. Variabel Bebas (independent variabel), Sebagai variabel bebas (independent variabel) dalam penelitian ini adalah kompetensi, independensi dan etika profesi.

1. $\operatorname{Integritas}\left(\mathrm{X}_{1}\right)$

Variabel ini diukur dengan mengadopsi instrumen yang digunakan oleh Ika Sukriah, Akram, Biana Adha Inapty. (2009) kuesioner yang di susun dari acuan BPKP. Variabel ini diukur dengan menggunakan skala interval (likert) 5 poin dari sangat tidak setuju (5), tidak setuju (4), netral (3), setuju (2) sampai sangat setuju(1).

2. Objektivitas $\left(\mathrm{X}_{2}\right)$ Variabel ini diukur dengan mengadopsi instrumen yang digunakan oleh Sukriah, Akram, Inapty (2009) kuesioner yang di susun dari acuan BPKP. Variabel ini diukur dengan menggunakan skala interval (likert) 5 poin dari sangat tidak setuju (5), tidak setuju (4), netral (3), setuju (2) sampai sangat setuju(1).

3. Profesionalisme $\left(\mathrm{X}_{3}\right)$

Variabel ini diukur dengan mengadopsi instrumen yang digunakan oleh (Irwansyah, 2010) dapat dicerminkan kedalam lima hal, yaitu: 1) Pengabdian pada profesi, 2) Pemenuhan kewajiban sosialnya, 3) Sikap kemandiriannya, 4) Keyakinan terhadap peraturan profesi, dan 5) Kualitas hubungannya dengan sesama profesi. Variabel ini diukur dengan menggunakan skala interval (likert) 5 poin dari sangat tidak setuju (5), tidak setuju (4), netral (3), setuju (2) sampai sangat setuju (1).

Model dan teknik analisis data dalam penelitian ini yaitu dengan menggunakan statistik deskriptif yang memberikan gambaran atau deskripsi suatu data yang dilihat dari nilai ratarata (mean), standar deviasi, varian, maksimum, minimum, sum, range, kurtosis, dan skewness (kemencengan distribusi) (Imam Ghozali, 2009:19).

1. Uji Kualitas Data

a. Uji Validitas, digunakan untuk mengukur sah atau valid tidaknya suatu kuesioner. Suatu kuesioner dikatakan valid jika pertanyaan pada kuesioner mampu untuk mengungkapkan sesuatu yang akan diukur oleh kuesioner tersebut (Imam Ghozali, 2009:49). Pengujianvaliditas dalam penelitian ini menggunakan Pearson Correlation yaitu dengan cara menghitung korelasi antara nilai yang diperoleh dari pertanyaan-pertanyaan. Apabila Pearson Correlation yang didapat memiliki nilai di bawah 0,05 berarti data yang diperoleh adalah valid (Imam Ghozali, 2009).

b. Uji Reliabilitas, adalah alat untuk mengukur suatu kuesioner yang merupakan indikator dari variabel atau konstruk. Suatu kuesioner dikatakan reliabel atau handal jika jawaban seseorang terhadap pernyataan adalah konsisten atau stabil dari waktu ke waktu (Imam Ghozali, 2009:45). Imam Ghozali (2009:46) menyebutkan bahwa pengukuran reliabilitas dapat dilakukan dengan dua cara, yaitu:

1) Repeated Measure atau pengukuran ulang: Disini seseorang akan disodori pertanyaan yang sama pada waktu yang berbeda, dan kemudian dilihat apakah ia tetap konsisten dengan jawabannya.

2) One Shot atau pengukuran sekali saja: Disini pengukurannya hanya sekali dan kemudian hasilnya dibandingkan dengan pertanyaan lain atau mengukur korelasi antar jawaban pertanyaan.

Kriteria pengujian dilakukan dengan menggunakan pengujian Cronbach Alpha $(\alpha)$. Suatu variabel dikatakan reliable jika memberikan nilai Cronbach Alpha $>0,60$ (Nunnaly, 1960 dalam Ghozali, 2009:46).

2. Uji Asumsi Klasik, Untuk melakukan uji 
asumsi klasik atas data primer ini, maka peneliti melakukan uji multikoloniearitas, uji normalitas, dan uji heteroskedastisitas. Uji normalitas bertujuan untuk mengukur apakah di dalam model regresi variabel independen dan variabel dependen keduanya mempunyai distribusi normal atau mendekati normal. Model regresi yang baik adalah memiliki distribusi normal atau mendekati normal. Dalam penelitian ini, uji normalitas menggunakan Normal Probability Plot(P-P Plot). Uji Multikoloniearitas, Pengujian multikoloniearitas bertujuan untuk menguji apakah pada model regresi ditemukan adanya korelasi antar variabel bebas (independen). Model regresi yang baik seharusnya tidak terjadi korelasi diantara variabel independen (Imam Ghozali, 2009:95). Deteksi ada atau tidaknya multikolinearitas di dalam model regresi dapat dilihat dari besaran VIF (Variance Inflation Factor) dan tolerance. Regresi bebas dari multikolinearitas jika nilai VIF $<10$ dan nilai tolerance $>0,10$ (Imam Ghozali, 2009:96). Uji heteroskedastisitas bertujuan menguji apakah model regresi terjadi ketidaksamaan varians dari residual satu pengamatan ke pengamatan yang lain. Jika varians dari residual satu pengamatan ke pengamatan yang lain tetap, maka disebut homoskedastisitas dan jika berbeda disebut heteroskedastisitas. Model regresi yang baik adalah homoskedastisitas (Imam Ghozali, 2009:125). Deteksi ada atau tidaknya heterokedastisitas dapat dilihat dengan ada tidaknya pola tertentu pada grafik scaterplot. Jika ada pola tertentu maka mengindikasikan telah terjadi heteroskedastisitas. Tetapi jika tidak ada pola yang jelas serta titik-titik menyebar di atas dan di bawah angka 0 pada sumbuY,makatidakterjadiheteroskedastisitas (Imam Ghozali,2009:125-126).

3. Pengujian Hipotesis

Penelitian menggunakan uji statistik untuk menguji apakah Integritas, Objektivitas, dan Profesionalisme secara simultan dan parsial mempengaruhi Kualitas Audit. Metode analisis yang digunakan untuk menguji hipotesis adalah analisis regresi.

a. Pengujian dengan Analisis Regresi Sederhana (Uji t)

Uji Regresi Parsial (Uji t) Pengujian ini bertujuan untuk menunjukkan seberapa jauh pengaruh satu variabel penjelas atau independen secara individual dalam menerangkan variasi variabel independen. Dengan tingkat signifikansi $5 \%$, maka kriteria pengujian adalah sebagai berikut: Bila nilai signifikansi $\mathrm{t}$ $<0.05$, maka $\mathrm{H}_{0}$ ditolak, artinya terdapat pengaruh yang signifikan antara satu variabel independen terhadap variabel dependen. Apabila nilai signifikansi $\mathrm{t}>$ 0.05 , maka $\mathrm{H}_{0}$ diterima, artinya terdapat tidak ada pengaruh yang signifikan antara satu variabel independen terhadap variabel dependen.

b. Pengujian dengan Analisis Regresi Ganda (Uji F)

Model regresi berganda bertujuan untuk memprediksi besar variabel dependen dengan menggunakan data variabel independen yang sudah diketahui besarnya (Singgih Santoso, 2004:163). Persamaan regresi ganda dirumuskan:

$\mathrm{Y}=\mathrm{a}+\mathrm{b} 1 \mathrm{X} 1+\mathrm{b} 2 \mathrm{X} 2+\mathrm{e}$ Integritas (X1), Objektivitas (X2) dan Profesionalisme (X3) berpengaruh secara simultan dan signifikan terhadap kualitas audit (Y) $\mathrm{Y}=\mathrm{a}+\mathrm{b} 1 \mathrm{X} 1+\mathrm{b} 2 \mathrm{X} 2+\mathrm{b} 3 \mathrm{X} 3+\mathrm{e}$

Dimana:

Y $\quad$ = Kualitas Audit

a $\quad=$ Konstanta

$\mathrm{b}=$ Koefisien Regresi

$\mathrm{X}_{1}=$ Integritas

$\mathrm{X}_{2}=$ Objektivitas

$\mathrm{X}_{3} \quad=$ Profesionalisme

Uji statistik $F$ menunjukkan apakah semua variabel independen atau bebas yang dimasukkan dalam model mempunyai pengaruh secara bersamasama terhadap variabel dependen atau terikat (Imam Ghozali, 2009:88). 
Kriteria uji koefisien regresi ganda dari variabel Integritas, Objektivitas dan profesionalisme terhadap kualitas audit adalah sebagai berikut:

Ha: Integritas, Objektivitas dan profesionalisme berpengaruh secara simultan dan signifikan terhadap kualitas audit.

\section{Hasil Penelitian Dan Pembahasan}

Peneliti mengambil sampel sebanyak 15 KAP dari keseluruhan KAP yang berada di wilayah Jakarta Selatan. Kuesioner yang disebarkan berjumlah 150 buah jumlah kuesioner yang kembali adalah sebanyak 96 kuesioner atau $64 \%$. Kuesioner yang tidak kembali sebanyak 54 buah atau $36 \%$, hal ini mungkin dikarenakan waktu penyebaran kuesioner yang kurang tepat. Kuesioner yang dapat diolah berjumlah 82 buah atau $85,4 \%$, sedangkan kuesioner yang tidak dapat diolah karena tidak memenuhi kriteria sebagai sampel dan tidak diisi secara lengkap oleh responden sebanyak 14 buah atau 14,6\%.
Data distribusi penyebaran kuesioner penelitian ini dapat dilihat pada tabel 1 .

Hasil Uji Statistik Deskriptif, variabel integritas jawaban minimum responden sebesar 48 dan maksimum sebesar 72 , dengan rata-rata total jawaban 58,49 dan standar deviasi sebesar 4,646. Variabel objektivitas jawaban minimum responden sebesar 15 dan maksimum sebesar 27, dengan rata-rata total jawaban 23,54 dan standar deviasi sebesar 2,654. Variabel profesionlisme minimum jawaban responden sebesar 48 dan maksimum sebesar 64 , dengan rata-rata total jawaban 55,85 dan standar deviasi sebesar 3,735. Sedangkan, pada variabel kualitas audit jawaban minimum responden sebesar 30 dan maksimum sebesar 45 , dengan rata-rata total jawaban 36,84 dan standar deviasi sebesar 3,187.

Hasil Uji Validitas, menunjukkan variabel Integritas mempunyai 13 kriteria valid dengan nilai signifikansi lebih kecil dari 0,05 . Dengan demikian 13 butir pertanyaan yang telah di uji validitasnya maka dapat digunakan sebagai uji analisis. Sedangkan Hasil Uji Reliabilitas menu-

Tabel I

Data Distribusi Sampel Penelitiaan

\begin{tabular}{clcc}
\hline No. & \multicolumn{1}{c}{ Nama Kantor Akuntan Publik } & $\begin{array}{c}\text { Kuesioner } \\
\text { dikirim }\end{array}$ & $\begin{array}{c}\text { Kuesioner } \\
\text { kembali }\end{array}$ \\
\hline 1 & KAP Bharata, Arifin, Mumajad \& Sayuti & 10 & 8 \\
2 & KAP Noor Salim, Nursehan \& Sinarahardja & 10 & 6 \\
3 & KAP Nugroho \& Rekan & 10 & 7 \\
4 & KAP Labib Y Wardiman \& Rekan & 10 & 4 \\
5 & KAP Drs. Mucharam \& Amron & 10 & 6 \\
6 & KAP Razikun Tarkosunaryo & 10 & 5 \\
7 & KAP Sasongko Mulyo & 10 & 6 \\
8 & KAP Usman \& Rekan (Pusat) & 10 & 5 \\
9 & KAP Abdul Ghonie Abubakar & 10 & 4 \\
10 & KAP Drs. Albert Silalahi \& Rekan & 10 & 7 \\
11 & KAP Drs. Ahmad Adri, MBA & 10 & 7 \\
12 & KAP Drs. Danny Sughanda & 10 & 10 \\
13 & KAP Drs. Basri Hardjosumarto, M.Si., Ak. \& Rekan & 10 & 7 \\
14 & KAP Gatot Permadi, Azwir \& Abimail & 10 & 8 \\
15 & KAP Hadori Sugiarto Adi \& Rekan & 10 & 96 \\
\hline
\end{tabular}

Sumber: Data Primer 
njukkan nilai cronbach's alpha atas variabel Integritas sebesar 0,850, Objektivitas sebesar 0,695, Profesionalisme sebesar 0,727, dan Kualitas Audit sebesar 0,820. Dengan demikian, dapat disimpulkan bahwa pernyataan dalam kuesioner ini reliabel karena mempunyai nilai cronbach's alpha lebih besar dari 0,60. Hal ini menunjukkan bahwa setiap item pernyataan yang digunakan akan mampu memperoleh data yang konsisten yang berarti bila pernyataan itu diajukan kembali akan diperoleh jawaban yang relatif sama dengan jawaban sebelumnya. Uji Normalitasi digunakan untuk menguji apakah dalam sebuah model regresi, variabel dependen dan variabel independen atau keduanya mempunyai distribusi normal atau tidak. Hasil Uji Normalitas menunjukkan penyebaran data yang berada disekitar garis diagonal dan mengikuti arah garis diagonal, ini menunjukkan bahwa model regresi telah memenuhi asumsi normalitas, meskipun masih ada yang sedikit melebar dari garis diagonal, untuk itu tidak cukup hanya melihat pada grafik P-plot untuk memastikan data ini apakah memenuhi asumsi kelasik normalitas maka dibutuhkan uji One-sample KolmogorovSmirnov agar memperkuat data ini terdistribusi normal atau tidak. hasil Asymp. Sig. (2-tailed) sebesar 0,306 dimana nilai Asymp. Sig. (2-tailed) lebih besar dari 0,05, sehingga uji One-Sample Kolmogorov-Smirnov Test menguatkan hasil dari grafik P-plot untuk itu data dapat memenuhi asumsi klasik normalitas atau data terdistribusi normal.

Uji Statistik t bertujuan untuk mengetahui secara individual pengaruh satu variabel independen terhadap variabel dependen. Jika nilai signifikan hasil uji $\mathrm{t}<0,05$ maka dapat disimpulkan bahwa secara parsial variabel integritas berpengaruh signifikan terhadap variabel kualitas audit. Pada gambar 2 disajikan hasil uji t terhadap variabel $\mathrm{Y}$ dan $\mathrm{X}_{1}$.

Dari hasil analisis data pada gambar $2 \mathrm{di}$ peroleh untuk model regresi Integritas : $\mathrm{Y}=6.390$ $+0,521 \mathrm{X}_{1}$ memperlihatkan nilai Sig hasil uji t sebesar 0,032 kurang dari 0,05, hal ini berarti menerima $\mathrm{H}_{2}$ sehingga dapat disimpulkan bahwa Integritas, secara parsial berpengaruh signifikan terhadap Kualitas Audit.

Untuk model regresi Objektivitas : $\mathrm{Y}=$ 38.947 - 0.089X. Koefisien determinasi sebesar -0,007 memperlihatkan nilai Sig hasil uji t sebesar 0,506 jauh lebih besar dari 0,05 , hal ini berarti

Gambar 2

Hasil Uji Normalitas Menggunakan Grafik P-Plot

\section{Normal P-P Plot of Regression Standardized Residual}

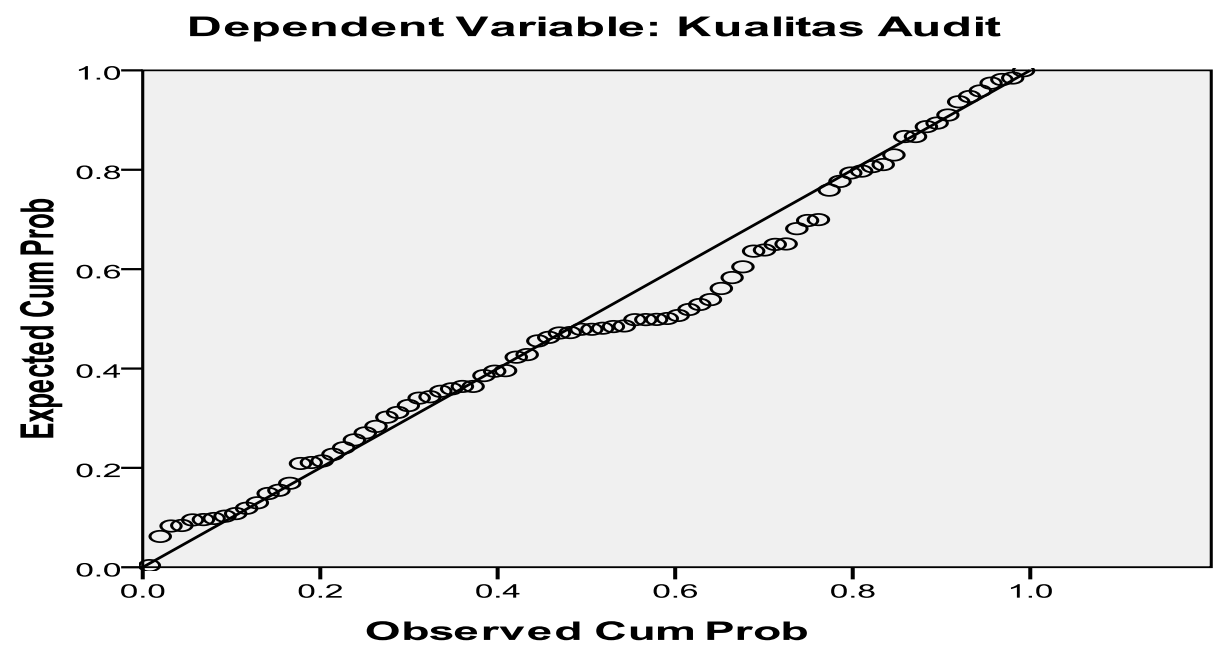


menerima $\mathrm{H}_{0}$ dan menolak $\mathrm{H}_{3}$ sehingga dapat disimpulkan bahwa Objektivitas, secara parsial tidak berpengaruh signifikan terhadap Kualitas Audit. Untuk pembahasan mengenai masingmasing variabel adalah sebagai berikut:

1. Pengaruh Integritas, Objektivitas dan Profesionalisme terhadap Kualitas Audit

Hasil uji hipotesis $\mathrm{H}_{1}$ menjelaskan integritas, objektifitas dan profesionalisme bersamasama berpengaruh terhadap kualitas audit. Auditor yang membangun karakter jujur dan teguh terhadap prinsip-prinsip seorang auditor dapat membantu auditor dalam menghasilkan kualitas audit sehingga menimbulkan kepercayaan positif kepada masyarakat. Objektifitas atau sikap tidak memihak, jujur secara intelektual, tidak berprasangka atau bisa serta bebas dari konflik kepentingan atau berada di bawah pengaruh pihak lain sikap ini dapat membantu untuk seorang auditor saat mengambil langkahnya agar tindakan-tindakan yang diambil tidak akan mendiskreditkan profesi auditor pada tekanan atau tuntutan yang diberikan oleh peran-peran yang dimiliki auditor tersebut dalam mencapai kualitas audit. Sedangkan profesionalisme pada auditor akan membantu seorang auditor memperoleh rasa tanggung jawab dalam menuntaskan kewajiban yang di embanya sebagai pemeriksa dengan seluruh keahlian yang dia miliki agar menghasilkan keputusan-keputusan yang diambil atau hasil pemeriksaan berkualitas tinggi, sehingga hasil audit memiliki kualitas yang baik. Hal ini menunjukkan bahwa apabila integritas, Objektivitas dan profesionalisme auditor tinggi, maka hal itu akan sangat mendukung sebuah kualitas audit. Hasil ini mendukung penelitian yang dilakukan oleh Mabruri dan Jaka (2010) yang menyatakan integritas memiliki pengaruh terhadap kualitas audit, sedangkan Inapty, Akram dan Sukriah (2009) dengan adanya objektivitas yang tinggi akan mempengaruhi kualitas audit, dan didukung pula dengan tingkat profesionalisme auditor yang di ungkapkan juga oleh Ida, Rawi dan Kamarudin (2011) dengan adanya sikap profesional pada auditor dapat meningkatkan kualitas audit.

2. Pengaruh Integritas terhadap Kualitas Audit

Hasil uji hipotesis $\mathrm{H}_{2}$ menjelaskan integritas berpengaruh positif terhadap kualitas audit. Hasil ini menggambarkan seorang auditor betapa pentingnya sebuah kejujuran dan keyakinan dalam membentuk karakter moral yang baik pada seorang auditor, karakter moral yang harus dimiliki seorang auditor dalam menjalankan kinerjanya sebagai

Tabel 2

Hasil Uji Statistik t Variabel

$\mathbf{Y}, \mathbf{X}_{1}$

Coefficients $^{\mathrm{a}}$

\begin{tabular}{|c|c|c|c|c|c|c|}
\hline \multicolumn{2}{|c|}{ Model } & \multicolumn{2}{|c|}{$\begin{array}{l}\text { Unstandardized } \\
\text { Coefficients }\end{array}$} & \multirow{2}{*}{$\begin{array}{c}\text { Standardized } \\
\text { Coefficients } \\
\text { Beta }\end{array}$} & \multirow{2}{*}{$\mathrm{t}$} & \multirow{2}{*}{ Sig. } \\
\hline 1 & (Constant) & B & Std. Error & & & \\
\hline \multirow{2}{*}{\multicolumn{2}{|c|}{ Integritas (X1) }} & 6.390 & 2.930 & & 2.181 & .032 \\
\hline & & .521 & .050 & .759 & 10.424 & .000 \\
\hline & 2 (Constant) & 38.947 & 3.172 & & 12.279 & .000 \\
\hline & Objektivitas (X2) & -089 & .134 & -.074 & -.668 & .506 \\
\hline & 3(Constant) & 48.697 & 5.172 & & 9.415 & .000 \\
\hline & Profesionalisme (X3) & -.212 & .092 & -.249 & -2.297 & .024 \\
\hline
\end{tabular}

a. Dependent Variable: Kualitas Audit (Y) 
pemeriksa laporan keuangan dapat membantu memperoleh kualitas audit yang baik. Hasil ini mendukung penelitian Mabruri dan Jaka (2010). Tetapi tidak sejalan dengan penelitian Inapty,Akram dan Sukriah (2009).

3. Pengaruh Objektivitas terhadap Kualitas Audit

Hasil uji hipotesis $\mathrm{H}_{3}$ menjelaskan objektivitas tidak berpengaruh positif terhadap kualitas audit. Hasil ini menggambarkan objektivitas seorang auditor dalam menjalankan tugasnya masih tidak memiliki pengaruh, mungkin saja seorang auditor masih terpengaruh terhadap kepentingan, atau pengaruh tekanan oleh klien dalam menjalankan perananya dalam bertugas sehingga tidak membantu seorang auditor dalam mencapai kualitas audit. Hasil ini tidak sejalan dengan penelitian Alim, Hapsari, dan Purwati (2007), Inapty,Akram dan Sukriah (2009). Mabruri dan Jaka (2010) yang menyatakan bahwa objektivitas berpengaruh terhadap kualitas auditor. Perbedaan ini di mungkin saja di sebabkan karena perbedaan waktu penelitian yang berbeda, dan lingkup populasi penelitian yang berbeda pula.

4. Pengaruh Profesionalisme terhadap Kualitas Audit

Hasil uji hipotesis $\mathrm{H}_{4}$ menjelaskan profesionalisme berpengaruh positif terhadap kualitas audit. Hasil ini menggambarkan dengan sikap profesionalisme seorang auditor akan melihatikan seberapa besar rasa tanggungjawab auditor dalam menjalankan peranannya sebagai auditor sehingga sanggat membantu bagi seorang auditor terhadap kualitas audit yang di hasilkan. Hasil ini sejalan dengan penelitian Ida, Rawi dan Kamarudin (2011) yang menyatakan bahwa motivasi dan profesionalisme berpengaruh terhadap kualitas auditor. Dimana dengan adanya sikap profesional pada auditor dapat meningkatkan kualitas audit.

\section{Kesimpulan, Keterbatasan Dan Implikasi Hasil Penelitian}

Penelitian ini bertujuan untuk mengetahui pengaruh integritas, objektivitas dan profesionalisme terhadap kualitas audit. Responden penelitian ini berjumlah 82 auditor dan pihak manajemn kantor yang terlibat dalam tugas pemeriksaan baik secara langsung atau tidak langsung yang bekerja di 15 Kantor Akuntan Publik (KAP) yang berada di Jakarta selatan dan berdasarkan Directory KAP yang diterbitkan oleh Institut Akuntan Publik Indonesia (IAPI) pada tahun 2013. Berdasarkan pada data yang telah dikumpulkan dan hasil pengujian yang telah dilakukan terhadap permasalahan dengan menggunakan model regresi sederhana dan regresi berganda, maka dapat diambil kesimpulan sebagai berikut:

1. Integritas, Objektivitas Dan Profesionalisme Berpengaruh Secara Simultan Terhadap Kinerja Auditor. Hal Ini Dapat Dijelaskan Oleh Besarnya Tingkat Signifikansi Sebesar 0,000. Hasil Penelitian Ini Konsisten Dengan Penelitian Yang Dilakukan Oleh Inapty,Akram dan Sukriah (2009) Semakin Obyektif Auditor Melakukan Pemeriksaan Maka Semakin Meningkat Atau Semakin Baik Kualitas Hasil Pemeriksaan Yang Dilakukannya. Mabruri Dan Winarna (2010) Semakin Obyektif Auditor, Dan Semakin Tinggi Integritas Seorang Auditor Maka Semakin Baik Kualitas Hasil Audit Yang Dilakukannya. Ida, Rawi Dan Kamarudin (2011) Menjelaskan Bahwa Profesionalisme Yang Tinggi Dan Ditunjang Dengan Motivasi Yang Tinggi Dari Aparat Inspektorat Akan Meningkatkan Kualitas Audit Yang Dilaksanakan.

2. Integritas berpengaruh positif terhadap kualitas audit. Hasil ini mendukung penelitian Havidz Mabruri dan Jaka Winarna (2010). Tetapi tidak sejalan dengan penelitian Alim, Hapsari, dan Purwati (2007) dan Ika Sukriah, Akram, Biana Adha Inapty. (2009).

3. Objektivitas tidak berpengaruh positif terhadap kualitas audit. Hasil ini tidak sejalan dengan penelitian Alim, Hapsari, dan Purwati (2007), Inapty,Akram dan Sukriah (2009), Mabruri dan Winarna (2010) yang 
menyatakan bahwa objektivitas berpengaruh terhadap kualitas auditor.

4. Profesionalisme berpengaruh positif terhadap kualitas audit. Hasil ini sejalan dengan penelitian Ida, Rawi dan Kamarudin (2011) yang menyatakan bahwa profesionalisme berpengaruh terhadap kualitas auditor. Dimana dengan adanya sikap profesional pada auditor dapat meningkatkan kualitas audit.

Penelitian ini mempunyai beberapa keterbatasan yang mungkin dapat melemahkan hasilnya. Beberapa keterbatasan dalam penelitian ini adalah sebagai berikut : (1) Tujuan riset di bidang akuntansi keprilakuan umumnya adalah untuk memprediksi dan menjelaskan fenomena perilaku yang terjadi atau memungkinkan terjadi, namun seperti diakui oleh banyak peneliti, sangat sulit memprediksi perilaku dengan tingkat kepastian yang tinggi; (2) Waktu penyebaran kuesioner penelitian ini ketika saat-saat para auditor sedang sibuk, sehingga (respon rate) kuesioner rendah; (3) Pemilihan variabel yang masih kurang dalam pengaruhnya terhadap kualitas audit; (4) Ruang lingkup penelitian ini hanya dilakukan di Jakarta selatan sehingga hasil penelitian ini terbatas generalisasinya.

Untuk penelitian selanjutnya diharapkan dapat menyajikan hasil penelitian yang lebih berkualitas lagi dengan adanya beberapa masukan mengenai beberapa hal diantaranya:

1. Para akuntan untuk dapat menjaga komitmen integritas, objektivitas dan profesionalismenya dalam melaksanakan profesi akuntan publik, serta selalu menjaga kepercayaan yang diberikan oleh masyarakat kepadanya.

2. Diharapkan organisasi Ikatan Akuntan Indonesia (IAI) dan Institut Akuntan Publik Indonesia (IAPI) menjaga dan memberikan pengawasan dan perlindungan kepada setiap akuntan pablik dalam menjaga komitmen integritas, objektivitas dan profesionalisme para auditor.

3. Diharapkan BAPEPAM terus menjaga dan meningkatkan peningkatan berkaitan dengan peraturan BAPEPAM bahwa setiap profesi penunjang pasar modal wajib memberikan penelitian yang independen untuk meningkatkan kualitas laporan keuangan perusahaan agar lebih dipercaya.

4. Para manajemen perusahaan yang terlibat dalam laporan informasi laporan keuangan dapat memeberikan informasi yang terbuka kepada para akuntan publik, agar akuntan publik dapat menjalankan sikap profesionalismenya dengan baik

5. Penelitian selanjutnya agar lebih memperhatikan waktu penelitian. Waktu penelitian diharapkan tidak dilakukan pada waktu sibuk auditor. Sehingga tingkat pengembalian (respon rate) kuesioner dapat lebih tinggi, dan mendapatkan hasil yang lebih akurat.

6. Penelitian lebih lanjut diharapkan dapat memperluas daerah survei, sehingga hasil penelitian lebih mungkin untuk disimpulkan secara umum.

\section{Daftar Pustaka}

Alim, M. Nizarul. Hapsari.T dan Purwanti.L. 2007. Jurnal. Pengaruh Kompetensi Dan Independensi Terhadap Kualitas Audit Dengan Etika Auditor Sebagai Variabel Moderasi. SNA X. Makassar.

Arens, Alvin A. Randal J.Elder, Mark S.Beasley, 2010. Auditing and Assurance Services and ACL Software. 13 th Edition. New Jersey : Prentice Hall.

Ghozali Imam. (2009) "Aplikasi Analisis Multivariate dengan program SPSS", Salemba empat. Jakarta.

Inapty.B, Akram, dan Sukriah I. (2009). Pengaruh Pengalaman Kerja, Independensi, Objektivitas, Integritas dan Kompetensi terhadap kualitas hasil pemeriksaan. Simposium Nasional Akuntansi XII. Palembang.

Institut Akuntan Publik Indonesia (2011). Standar Profesional Akuntan Publik. Jakarta.

Irwansyah. 2010. Pengaruh ketaatan kompetensi dan independensi akuntan publik terhadap profesionalisme akuntan publik dan 
implikasinya atas kualitas audit, survei pada akuntan publik yang menjadi anggota FAPB. Disertasi. Universitas Padjajaran Bandung.

Jensen, M. C. and W. H. Meckling. 1976. Theory of the Firm: Managerial Behaviour, Agency Cost, and Ownership Structure. Journal of Financial Economics 3, hlm. 305-60

Kamarudin, Rawi, dan Ida R. 2011. Jurnal. Dampak Motivasi Dan Profesionalisme Terhadap Kualitas Audit Aparat Inspektorat dalam pengawasan keuangan daerah. Jurnal Akuntansi volume XV/03/Juli/2011. Jakarta: Candi Mas Metropole.

Mabruri H dan Jaka W. 2010. Analisis FaktorFaktor Yang Mempengaruhi Kualitas Hasil Audit di Lingkungan Pemerintah Daerah. Simposium Nasional Akuntansi XIII. Purwokerto.

Mardisar, Diani. Sari.R.N. 2007. Pengaruh Akuntabilitas dan Pengetahuan Terhadap Kualitas Hasil Kerja Auditor. SNA X. Makassar. 